\title{
An exploration of sales activities from a service ecosystems perspective
}

\author{
Nathaniel N. Hartmann, Heiko Wieland and Bruno \\ Lussier
}

As scholars have pointed to, it seems as if selling is going through a major transition (Hartmann, Wieland, and Vargo 2018; Marshall et al. 2012; Moncrief 2017). Beginning in the 1970s, relationship sales orientations (long-term, partnership, and mutual benefit focus) have steadily replaced transactional (short-term, salesperson vs. buyer, and maximization of self-interest) sales orientations. These relationship sales orientations have evolved, as exemplified by consultative and enterprise selling, to increasingly recognize the participation of greater and broader sets of actors in selling (Jolson 1997; Rackham and DeVincentis 1998; Weitz and Bradford 1999). Moreover, the literature now recognizes the broad engagement of salespeople with large sets of actors, both internal and external to selling organizations (Evans et al. 2012; Plouffe and Barclay 2007; Plouffe, Sridharan, and Barclay 2010; Plouffe et al. 2016) and views sales processes as embedded in service ecosystems (i.e., dynamic systems in which actors integrate and exchange resources to create value for themselves and for others) (Hartmann, Wieland, and Vargo 2018). The advent and proliferation of digital technologies (e.g., computers, mobile devices, internet, email, customer relationship management software, and artificial intelligence) have contributed to more connected, informed, and dynamic actors (e.g., buyers, sellers, journalists) throughout ecosystems (Andzulis, Panagopoulos, and Rapp 2012; Marshall et al. 2012). Partially attributable to the aforementioned, salespeople of today must address increasingly dynamic changes in the demands of broad stakeholders (e.g., sales organization members, customers' organizations, suppliers) and resources (e.g., technologies). This leads to an environment where salespeople are regularly and increasingly asked to perform new activities, and shift activities that they are used to performing to other actors or technological tools (Marshall, Moncrief, and Lassk 1999). 
Such changes and transitions in selling have led to substantial debate amongst scholars and practitioners regarding issues including, but not limited to: (a) what selling is and is not, (b) who performs selling, (c) whether the importance of selling activities is increasing or decreasing, and (d) whether the importance of salespeople will increase or decrease (Hartmann, Wieland, and Vargo 2018). This debate highlights substantial concern regarding the uncertain future of selling and sales management practice and theory (Chonko et al. 2002; Moncrief 2017; Wilson 2000). However, as Hartmann, Wieland, and Vargo (2018) point out, continual changes do not "necessarily alter what selling entails, how salespeople participate in value creation, and/or the importance of salespeople" (Hartmann, Wieland, and Vargo 2018, p. 1). Thus, there remains great need to explicate what selling fundamentally is, how actors, such as salespeople, engage in selling, as well as how technologies and other changes to markets affect selling processes. In response to this need, we build on the work of Hartmann, Wieland, and Vargo (2018) and others (Hughes, Le Bon, and Rapp 2013; Rapp et al. 2017) to contribute to a holistic and systemic theoretical foundation for sales. In particular, we examine sales activities and identify the three core components foundational to these activities.

The remainder of this chapter is organized as follows. First, to inform readers of the perspective through which we view selling, we briefly introduce service-dominant (S-D) logic and its service ecosystems perspective as well as concepts from institutional theory. Second, we discuss exchange in ecosystems and the role of selling and salespeople in such exchange. Third, we argue that recent changes in selling processes and activities reveal the need for a new theoretical sales framework. Fourth, we describe the activities salespeople perform and point to the tension between activities that vary over time and commonalities that underlie such activities to highlight that our framework can offer rich insights into understanding this tension.

\section{Theoretical foundations}

This work draws from the service ecosystems perspective of S-D logic (Vargo and Lusch 2004, 2016, 2017; Wieland, Hartmann, and Vargo 2017) and institutional theory to inform understanding of selling and salesperson activities. Since some readers might not be familiar with S-D logic and institutional theory, we provide a cursory review of both below. 


\section{Service-dominant logic}

Following the publication of the article "Evolving to a New Dominant Logic for Marketing" (Vargo and Lusch 2004), service-dominant (S-D) logic has developed into a rich research stream. In this, and many other subsequent works, Vargo and Lusch (e.g., 2008, 2016) describe a needed shift in thinking from a goods-dominant to a service-dominant logic, supported by eleven foundational premises. Focal to S-D logic is the notion that service-for-service exchange can explain, and is foundational to, all economic and marketing activities (Vargo and Lusch 2017). S-D logic uses the service term to refer to the application of one actor's resources for the benefit of another actor. That is, S-D logic highlights the primacy of service, which can be exchanged directly or indirectly through the exchange of goods or currencies. An example of a direct application of service is a salesperson applying her knowledge and skills to help buyers understand changing markets and potential solutions to problems. An example of indirect exchange of service is a manufacturing firm that uses its knowledge and skills to develop and deliver a good to a buyer. Monetary payment from the buyer to the seller also exemplifies indirect exchange of service as currency is a medium acquired via the application of knowledge and skills. Thus, S-D logic, by highlighting the primacy of service, differed from much of the extant marketing literature, which was goods focused and commonly described services as inferior goods (based on the "IHIP" characteristics-intangibility, heterogeneity, inseparability of production and consumption, and perishability (Zeithaml, Parasuraman, and Berry 1985)).

Specifically, Vargo and Lusch point to resources that act on other resources (i.e., operant resources, such as knowledge and skills) as being primary to service exchange and value cocreation. Drawing from Zimmermann (1951), Vargo and Lusch (2004) argue that "resources are not; they become" (p. 3). That is, resources do not possess inherent value but only become resources when actors learn how a resource can be used to create value. Rare earth elements, for example, were viewed as dirt before humans learned how to use them to build a wide range of electronic devices. Furthermore, Vargo and Lusch (2016), drawing from network and system theories, among others, reveal that "value is cocreated by multiple actors, always including the beneficiary" (p. 8). That is, value cocreation occurs in systems of actors (i.e., service ecosystems) as the resources involved in service exchange commonly are provided by a large number of sources. For example, exchange between a manufacturing firm of audio equipment and Ford Motor Company often entails resources provided by government (e.g., roadways, legal systems, currencies), various educators (e.g., trade magazines that feature or review offerings, presenters at conferences and trade fairs related to automobiles), prior customers of the manu- 
facturing firm (e.g., customer reviews), and other manufacturers who develop supporting products (e.g., wires, fuses). Furthermore, as we will describe in the following section, the behavior of actors in service ecosystems (e.g., exchange and value cocreation practices) are both enabled and constrained by human created institutions (Vargo and Lusch 2016).

\section{Institutional theory}

Institutional theory is a prominent theory regularly featured in management and sociology research to explain the behavior of organizations and individuals. Early marketing work (Alderson 1957; Duddy and Revzan 1953; Revzan 1968; Weld 1916) points to the potential of institutional and systemic thinking to inform understanding of actor roles, and relationships and transactions among actors. Despite such early attention, institutional and systemic thinking were long overlooked by the marketing and sales literatures. Nevertheless, recent work (Hartmann, Wieland, and Vargo 2018; Humphreys 2010; Vargo and Lusch 2016; Wieland, Hartmann, and Vargo 2017) has renewed interest in the potential of institutional and systemic thinking to advance understanding of marketing and sales related phenomenon. As an example of such interest and potential, Vargo and Lusch (2016, p. 5) point to institutions and institutional arrangements as being "the keys to understanding human systems and social activity, such as value cocreation, in general."

Institutions refer to coordinating heuristics (e.g., norms, assumptions, practices, values, beliefs) that enable and constrain thinking and behavior (Scott 2013). Scott explains that "institutions provide stimulus, guidelines, and resources for acting as well as prohibitions and constraints on actions" (p. 58). Specifically, institutional arrangements- "interdependent sets of institutions" (Vargo and Lusch 2016, p. 6) -aid actors in exchange by serving as sets of "value assumptions, cognitive frames, rules, and routines" (Vargo and Lusch 2016, pp. 14-15). Institutions and institutional arrangements serve as a means of simplifying the thinking and practices of human actors and therefore help human actors deal with their inherent cognitive, skill, and time limitations. Many interactions between buyers and sellers are enabled and constrained by institutions from domains such as professional behavior, friendships, and cultural norms. 


\section{Why is selling and why are salespeople important?}

\section{Exchange and crossing points}

In order to understand the importance of selling and salespeople to both exchange and value creation, it is essential to understand why actors participate in exchange. Actors participate in exchange in order to benefit from the respective differences of knowledge and skills between themselves and other actors. That is, actors often elect to specialize in developing and acting on particular knowledge and skills which permit them to perform certain tasks better and more efficiently than they otherwise could. The tradeoff is that actors who specialize can lose or fail to develop the knowledge and skills required to complete other tasks that are part of the larger task system and actors commonly participate in value cocreation processes without the knowledge to fully understand or perform entire sets of these processes (Hartmann, Wieland, and Vargo 2018). A buyer for a Fortune 500 company, for example, often understands negotiation tactics and essential information (e.g., specifications, compatibilities, prices) relating to what resources are sought from suppliers, but might not have the knowledge of how to combine these resources with others to produce desired outcomes (e.g., the manufacturing process).

This division of labor, exchange, and value creation among broad sets of humans points to the importance of applying systemic views. While systemic views have so far received limited attention in the sales literature, such views have been used by a substantial number of works in marketing, management, information technology, sociology, and biology, among others. In totality, the literature provides strong support for the broad applicability of systems views. Simon (1996), for example, reveals that broad phenomenon can be viewed as occurring in hierarchically organized systems comprised of lower-order and interacting subsystems. To illustrate this, consider that an industry is composed of many firms which are composed of many business units, departments, and teams. That is, in this example, the industry is a system composed of nested subsystems such as firms, business units, and departments. Likewise, dynamic social systems such as societies are composed of interdependent subsystems such as individual actors, family units, communities, cities, and nations (Simon 1996).

In these systems and subsystems, many tasks are relatively interdependent from those in other systems. Baldwin and Clark (2000) use the term modules to explicate the interactions between and among such system components. They explain that modules are "group[s] of elements, such as tasks, that are highly interdependent on one another but only minimally dependent on what 
happens in other modules" (p. 63). To illustrate, consider that a task (e.g., prospecting) performed within the sales functional area tends to be much more intertwined and similar to other tasks (e.g., qualifying, delivering a presentation) in the sales functional area relative to tasks within finance, accounting, operations or other functional areas. Moreover, a task performed within a manufacturing facility of a selling firm tends to be more intertwined and similar to other tasks performed within the manufacturing facility relative to tasks performed by the buyer. Hence, exchange takes place between modules within and across actors or sets of actors.

Hartmann, Wieland, and Vargo (2018) draw from the work of Baldwin (2008) to refer to "the location (between modules) at which service can be exchanged for service" (p. 7) as a crossing point. Such crossing points can be described as "thin" or "thick" (Baldwin and Clark 2000; Hartmann, Wieland, and Vargo 2018). Using the work of institutional (e.g., North 1990) and marketing (e.g., Kjellberg and Helgesson 2006) scholars, Hartmann, Wieland, and Vargo (2018) explain that thin crossing points occur when actors align on relational and formal contracts, regulations, laws, shared meanings, conceptualizations of what is being exchanged, and exchange practices, as well as other norms and representations. The formation of such contracts, regulations, practices, norms, and representations (i.e., institutions) requires the direct and indirect involvement of broad sets of actors. Hence, thin crossing points form when institutional arrangements are aligned across such actor sets. As institutional alignment increases, the costs of engaging in exchange decreases. In contrast to thin crossing points, thick crossing points occur when norms and representations are unclear or incompatible. When norms and representations are misaligned, actors seeking exchange must often develop deeper and more complex relationships. Not surprisingly, such misalignments increase transaction costs and may even prevent exchange.

\section{Selling as the thinning of crossing points}

The above section points out that all actors are embedded in systems and that these actors are resource integrators who benefit from their respective advantages in knowledge and skills through exchange. The crossing point term refers to the locations at which such exchange takes place, and crossing points can be described as thin and thick depending on the institutional alignments that shape the exchange. Thin (thick) crossing points can be characterized as a high (low) degree of agreement on what is being exchanged (e.g., performance, durability), the exchange process, and relational norms among things. Below, we further discuss the thinning of crossing points to facilitate exchange before turning our attention to the importance of selling and salespeople in doing so. 
Institutional alignment among actors mandates the creation, maintenance, and disruption of institutions. Lawrence and Suddaby (2006) call these creation, maintenance, and disruption processes institutional work. That is, institutional work occurs as interconnected actors attempt to not only resolve and conceal tensions and conflicts, but also support commonalities in their institutional arrangements (Zietsma and McKnight 2009). The participation of many actors in institutional work over time points to the broad and systemic nature of institutional change processes (Hartmann, Wieland, and Vargo 2018). Furthermore, it points to the enabling and constraining properties of institutional arrangements in shaping the practices of actors (i.e., by providing the ability to interpret and mobilize an array of resources) (Bourdieu 1977; DiMaggio and Powell 1983; Giddens 1984; Sewell 1992), as well as the limited ability of single actors (e.g., a salesperson) to change the institutions of others. This indicates, as Hartmann, Wieland, and Vargo (2018) point out, that while selling is often viewed as a micro-level process in which salespeople thin crossing points (i.e., align institutional arrangements to facilitate service exchange), selling must be viewed as a process that involves many actors in both the thinning and thickening of crossing points. To exemplify, consider that broad sets of actors can choose to participate in shaping perceived value perceptions of solutions, both through resource integration practices and the participation in narratives. At the present time, for example, government actors, security analysts, media members, employees of many companies, and ordinary citizens are participating in a dialogue about the safety and viability of widespread autonomous vehicles. While the thinning of crossing points relating to a seller's solution can lead to the solution being accepted, the thickening of crossing points for competitor solutions can result in such solutions being perceived as flawed or insufficient. Hence, as crossing points regarding use of autonomous vehicles in transportation solutions thin (e.g., efficiency, effectiveness, and safety increases relative to human driven vehicles), crossing points regarding use of human driven vehicles can thicken (e.g., efficiency, effectiveness, and safety decreases relative to autonomous vehicles) resulting in transportation solutions dependent on human driven vehicles being less viable and sustainable.

\section{Salespeople and changes in sales orientations}

Oscillating foci among micro (i.e., individuals, firms), meso (i.e., professions, industries, markets), and macro (i.e., societal) perspectives, particularly across time, can reveal institutional work processes that shape value creation 
practices (Chandler and Vargo 2011; Hartmann, Wieland, and Vargo 2018). Autonomous transportation solutions, for example, are coming about at least partially because of the institutionalization of perceptions regarding safety, feasibility, efficiency, and effectiveness shared by many actors (e.g., executives, engineers, legislators, users, consumers, activists) based on, and resulting in, the development of vehicles and pilot programs for personal transportation solutions. Below, we discuss the evolution of transactional to relational sales orientations to illustrate how such formation, maintenance, and disruption of institutions aids value creation and can result in changes of salesperson and other actors' activities.

The transactional selling orientation is deeply rooted in mass manufacturing popularized during the late-nineteenth and early-twentieth centuries (Vargo and Lusch 2004). At the time, value was commonly viewed as being embedded in goods via manufacturing and realized by buyers as the good was consumed. This view promoted a salesperson role that was relatively limited in scope and activities (Jolson 1997). Salespeople, for example, were encouraged to use aggression and persuasion to convert prospects into customers using standardized sales presentations and pushy closing techniques. Coinciding with the narrow, short-term focus of this orientation, the importance of the salesperson maximizing revenue and profit in each exchange, manipulating the buyer, and winning the negotiation was emphasized (Jolson 1997).

The viability of the transactional selling organization was increasingly questioned in the 1960s and 1970s as, among other things, buying processes became more thorough and complex, buyers received greater training, and sales organizations placed greater emphasis on ensuring predictable and sustainable revenues and profits. Furthermore, practitioners increasingly recognized the importance of solutions which were composed of intangible and tangible elements. Rolls-Royce's Power-by-the-Hour solution, which included tangibles (e.g., jet engines, lubricants) as well as intangibles (e.g., engine maintenance and diagnostics), exemplifies such a development. It was during the 1970s that practitioners began to substantively recognize the importance of the buyer-seller relationship to the purchase of such expansive solutions as well as predictable and sustainable long-term revenue and profit (e.g., Dwyer, Schurr, and Oh 1987; Weitz and Bradford 1999). The relationship selling orientation promoted the salesperson role as being strategically important and being more expansive in scope and activities relative to the past. Salespersons, for example, were encouraged to seek out leads likely to have needs that the selling firm could fulfill, use questions to deeply understand the buyer's problems and concerns, use adaptive selling, and practice less manipulative closing techniques (Jolson 1997). Relationship selling emphasizes the importance of 
salespeople developing relationships with buyers characterized by high levels of salesperson empathy, trust, awareness, and credibility that result in benefits, often long-term, to both the buying and selling organization (Jolson 1997).

Coinciding with such focus on relationship selling has been the development and proliferation of consultative and enterprise selling orientations (Rackham and DeVincentis 1998). Rackham and DeVincentis (1998), for example, point to the importance of salespeople in helping buyers understand broad factors of their business. These factors include the intricacies of how the buyers' particular contexts (e.g., industry, organizational size, type of employees, competitor developments, product and service offerings) influence needs and the importance of products/service features. Furthermore, salespeople are involved in the development and implementation of customized (to particular buyer circumstances) solutions, informing and involving broader selling firm actors in interactions (e.g., employees in new product development, finance, legal, accounting, and other functions), and performing non face-to-face tasks (e.g., forecasting, developing proposals, transferring knowledge internally). Enterprise selling extends consultative selling to connect many employees, from different functions, of the selling and buying organization. It assumes that by connecting broad sets of actors, the transfer and application of knowledge and skills between the selling and buying organization increases, as does the integration of both organizations.

Scholars and practitioners generally recognize that relationship selling has increased value creation by bringing about substantial change to the activities of various actors (e.g., salespeople, buyers, and other actors), often expanding the set of activities and actors involved in selling and buying processes. Coinciding with the evolution of relationship selling has been the advent and proliferation of existing and emerging digital technologies (e.g., computers, mobile devices, internet, email, customer relationship management software, and artificial intelligence) which have contributed to rapid changes in the demands of broad stakeholders (e.g., sales organization members, customers' organizations, suppliers). These proliferations have eased communication across sets of actors, broadened the number of actors involved in selling and buying processes, brought about the need for actors to perform new selling and buying activities, and shifted some activities involved in selling and buying processes from certain human actors to other human actors or technologies (Marshall, Moncrief, and Lassk 1999). This has motivated substantial debate regarding many issues including: (a) what selling is and is not, as well as (b) who performs selling, (c) whether the importance of selling activities is increasing or decreasing, and (d) whether the importance of salespeople will increase or decrease. 
Broadening the perspective through which a phenomenon is examined can permit the resolution of tensions and paradoxes (Vargo and Lusch 2017). Hence, as stated, in responding to the aforementioned debate, Hartmann, Wieland, and Vargo (2018) point to the importance of adopting views that recognize sales processes as being embedded in dynamic complex systems and advance a service ecosystems perspective as a theoretical framework of selling which they argue "better explicates the processes and roles of selling in value cocreation through market exchange" (Hartmann, Wieland, and Vargo 2018, p. 1). Hartmann, Wieland, and Vargo (2018) define selling as "the interaction between actors aimed at creating and maintaining thin crossing points-the locations at which service can be efficiently exchanged for service-through the ongoing alignment of institutional arrangements and the optimization of relationships" (p. 9). As they point out, this reveals that very broad sets of human actors participate in selling and that selling is, and will always be, important. However, this systemic perspective also shows that how actors participate in selling regularly changes. Hartmann, Wieland, and Vargo (2018), for example, conclude that the importance of particular roles such as salespeople in selling processes is contextual and subject to variation across industry, company, responsibilities, time, and technological developments, etc.

\section{Sales activities}

In the paragraphs above, we have briefly reviewed the transition from transactional to relational selling, and discussed how the combination of relational selling and digital technologies have led to substantial debate in the sales literature. We have also summarized Hartmann, Wieland, and Vargo's (2018) response to such debate which advances a service ecosystemic and institutional framework, resulting in a novel definition of selling. Below, we draw on this framework and selling definition to advance understanding of the activities that comprise selling.

On the one hand, "it is not uncommon for salespeople to be perceived as basically all performing the same set of activities, regardless of industry, product, or organizational philosophy" (Marshall, Moncrief, and Lassk 1999, p. 89). On the other hand, the existence of a substantial number of sales roles, such as hunter/gatherer, inside/outside, consultative, new business/channel development, missionary, delivery, order taker, technical, trade, support, and key account manager, points to great variations across salespeople and the activities such salespeople perform. Underlying such terminology, at least at the time of each role's creation, is usually the intent to recognize differences across 
sales roles with respect to the length and complexity of the selling process, duration of the relationship with the customer, customer type with whom the salesperson does business, importance of and ability to respond to customer needs uniquely via customized solutions, time allocated to and importance of recruiting new customers, and time and type (e.g., face-to-face, email, phone, virtual) of customer contact, among other aspects.

While scholars have intermittedly examined the activities salespeople perform (e.g., Churchill, Ford, and Walker 1978; Cravens et al. 1993; Lamont and Lundstrom 1974; Marshall, Moncrief, and Lassk 1999; Moncrief 1986), sales-focused academics and practitioners have long struggled to find consensus on a clear typology and understanding of salesperson activities (Cravens et al. 1993; Marshall, Moncrief, and Lassk 1999). Much of this struggle has, arguably, been attributed to changes in salesperson activities brought about by changes in markets and technologies. Marshall, Moncrief, and Lassk (1999), for example, point to, in what is arguably the most encompassing examination of salesperson activities, changes in markets and technologies during the 1980s and 1990s as motivating substantial change in the activities performed by salespeople. These authors not only examine the activities salespeople performed in 1999, but also compare and contrast these activities with those previously identified by others (see Churchill, Ford, and Walker 1978; Lamont and Lundstrom 1974), and in particular to the work of Moncrief (1986).

The earlier work of Moncrief (1986) used data collected in the early 1980s to generate a list of 121 broad ranging sales activities and group these activities into categories including relationship selling, promotional activities and sales service, entertaining, prospecting, computer, travel, training/recruiting, delivery, product support, educational activities, office, and channel support. While Marshall, Moncrief, and Lassk (1999) conclude "that very few, if any, of the old activities from 1986 have gone away" (p. 97), these authors do introduce 49 activities not represented in the list of 121 reported by Moncrief (1986). Marshall, Moncrief, and Lassk (1999) attribute the increase in activities to increases in the breath of selling methods, advancement in communication technologies, as well as increases in the number of selling firm actors involved in selling efforts. These authors group these new activities into task categories including communication, sales, relationship, team-building/team-selling, and database management.

In order to address this tension between change and continuity in sales activities, Marshall, Moncrief, and Lassk highlight the need to regularly analyze the activities salespeople perform, the broader supporting activities performed by others, and technological changes (e.g., recruitment and selection, training, 
information management). Many would argue that this need is particularly current given the increased involvement of salespeople in post-sales customer interactions as well as the implementation of digital technologies (i.e., computers, mobile devices, internet, email, customer relationship management software, and artificial intelligence) which have brought about changes to the activities salespeople perform. Scholars have, for example, pointed out that salespeople are increasingly involved in activities (e.g., communicate information post purchase, demonstrate interest and concern post purchase, respond quickly and sufficiently to post-purchase requests) once relegated to those of customer service personnel (e.g., Ahearne, Jelinek, and Jones 2007; Rapp et al. 2017). Additionally, scholars have described selling and other activities performed by salespeople and others over digital technologies including social media (e.g., Agnihotri et al. 2012; Nunan et al. 2018), as well as the ability of digital technologies to support human actors in performing activities and shift performance of activities to digital technologies or other actors (e.g., Singh et al. 2019).

While we agree with the need for regular empirical analyses of sales activities, we argue that it is also important to scrutinize sales activities for commonalities and differences. Such scrutiny may lead to a theoretically informed typology to guide future empirical work on sales activities. We believe that our systemic framework can be used to inform such a typology, as it accounts for the tension between change and continuity and clarifies what selling is and consists of. Specifically, the definition of selling advanced by Hartmann, Wieland, and Vargo (2018) identifies three core components in the thinning of crossing points that are foundational to all sales processes: (1) the establishment of mutual definitions of what is being reciprocally exchanged, (2) the establishment of the norms and representations that guide exchange practices, and (3) the establishment of relational norms, such as flexibility, solidarity, mutuality, harmonizing of conflict, and restraint in the use of power, in safeguarding relationships.

Using these three core components helps to distinguish between sales activities and the activities salespeople perform. As a detailed examination of the activities listed by Moncrief (1986) and Marshall, Moncrief, and Lassk (1999) illustrates, our framework indicates that many of the activities salespeople perform are not direct sales activities (e.g., travel out of town, report sales activities, attend sales meetings). Figure 1.1 helps to illustrate these differences between supporting or administrative activities and sales activities. Furthermore, Figure 1.1 shows that order taking and order management can be treated as related but distinct salespeople activities. Additionally, salespeople activities can be viewed at various levels of aggregation. Marshall, Moncrief, and Lassk (1999), 
for example, describe providing and receiving feedback from clients as sales activities. Such feedback, for example, can be part of higher-level activities such as overcoming objections or modifying a product. Arguably, our framework can also help to identify an appropriate level of aggregation.

\begin{tabular}{|c|c|c|c|c|}
\hline \multicolumn{5}{|c|}{ Sales* Activities } \\
\hline $\begin{array}{c}\text { Establish } \\
\text { mutual } \\
\text { definitions of } \\
\text { what is being } \\
\text { reciprocally } \\
\text { exchanged. } \\
\end{array}$ & \begin{tabular}{|c|} 
Establish the \\
norms and \\
representations \\
that guide \\
exchange \\
practices.
\end{tabular} & $\begin{array}{c}\text { Establish mutually } \\
\text { beneficial } \\
\text { relationships. }\end{array}$ & $\begin{array}{c}\text { Maintain existing } \\
\text { exchange practices. }\end{array}$ & $\begin{array}{l}\text { Provide company } \\
\text { internal activities. }\end{array}$ \\
\hline $\begin{array}{l}\text { - Prepare } \\
\text { visual displays } \\
\end{array}$ & $\begin{array}{l}\text { - Submit price } \\
\text { bids }\end{array}$ & $\begin{array}{l}\text { - Entertain } \\
\text { clients }\end{array}$ & - Write up orders & $\begin{array}{l}\text { - Check in with } \\
\text { supervisor }\end{array}$ \\
\hline $\begin{array}{l}\text { - Demonstrate } \\
\text { the product }\end{array}$ & $\begin{array}{l}\text { - Help find } \\
\text { financing }\end{array}$ & $\begin{array}{l}\text { - Take clients to } \\
\text { dinner/drinks }\end{array}$ & $\begin{array}{l}\text { - Predict closure } \\
\text { dates }\end{array}$ & $\begin{array}{l}\text { - Fill out expense } \\
\text { accounts }\end{array}$ \\
\hline $\begin{array}{l}\text { - Order } \\
\text { samples }\end{array}$ & $\begin{array}{l}\text { - Handle } \\
\text { shipment } \\
\text { problems }\end{array}$ & $\begin{array}{l}\text { - Research } \\
\text { clients' } \\
\text { background } \\
\end{array}$ & - Expedite orders & $\begin{array}{l}\text { - Reports on sales } \\
\text { activities }\end{array}$ \\
\hline $\begin{array}{l}\text { - Read trade } \\
\text { publications }\end{array}$ & $\begin{array}{l}\text { - Avoid } \\
\text { potential } \\
\text { litigation }\end{array}$ & $\begin{array}{l}\text { - Send thank-you } \\
\text { communications }\end{array}$ & $\begin{array}{l}\text { - Handle back } \\
\text { orders }\end{array}$ & $\begin{array}{l}\text { - Travel with } \\
\text { supervisors }\end{array}$ \\
\hline $\begin{array}{l}\text { - Modify } \\
\text { product }\end{array}$ & $\begin{array}{l}\text { - Study } \\
\text { market trends }\end{array}$ & $\begin{array}{l}\text { - Build rapport } \\
\text { with buying } \\
\text { center }\end{array}$ & $\begin{array}{l}\text { - Handle shipment } \\
\text { problems }\end{array}$ & $\begin{array}{l}\text { - Attend regional } \\
\text { sales meeting }\end{array}$ \\
\hline $\begin{array}{l}\text { - Sell value- } \\
\text { added services }\end{array}$ & $\begin{array}{l}\text { - Determine } \\
\text { legalities }\end{array}$ & $\begin{array}{l}\text { - Make guest } \\
\text { speeches }\end{array}$ & - Find lost orders & $\begin{array}{l}\text { - Attend periodic } \\
\text { training }\end{array}$ \\
\hline $\begin{array}{l}\text { - Monitor } \\
\text { competitor's } \\
\text { products }\end{array}$ & $\begin{array}{l}\text { - Politicking } \\
\text { outside }\end{array}$ & $\begin{array}{l}\text { - Take clients on } \\
\text { site }\end{array}$ & $\begin{array}{l}\text { - Follow up client's } \\
\text { order }\end{array}$ & $\begin{array}{l}\text { - Train new } \\
\text { salespeople }\end{array}$ \\
\hline
\end{tabular}

Note: *Sales activities establish mutual definitions of what is being reciprocally exchanged; establish the norms and representations that guide exchange practices; establish mutually beneficial relationships that provide flexibility, solidarity, mutuality, harmonizing of conflict, etc.

Source: Based on Marshall, Moncrief, and Lassk (1999).

Figure 1.1 Examples of activities that are often either sales or supporting

\section{Sales activities and the larger context}

As we will discuss next, the three core components that are foundational to all sales processes - those that contribute to the thinning of crossing pointscannot be understood as discrete events between dyadic buyers and sellers, but need to be viewed in a larger institutional context. As stated, while "it is 
tempting to view selling as a micro-level process in which dyads of buying and selling actors are engaged in the thinning of crossing points (i.e., in aligning institutional arrangements for service exchange), selling can only be fully understood by oscillating foci among micro, meso, and macro perspectives" (Hartmann, Wieland, and Vargo 2018, p. 9).

Perceptions about what is being reciprocally exchanged, for example, are not only shaped by a sales presentation from a salesperson or by the inspection of a product sample from a potential buyer, but also from perceptions of competing products, word-of-mouth from users and non-users, and evaluations from industry experts, just to name a few. Similarly, the norms and representations that guide exchange practices, including routinized activities related to economic exchange, are shaped through the institutional work processes of broad sets of actors (Kjellberg and Helgesson 2006; Wieland, Koskela-Huotari, and Vargo 2016). Such norms and representations can include diverse sets of institutions such as industry norms on price mechanisms, technological standards, common payment terms, antitrust laws, and enactments of markets. Even seemingly dyadic relational norms are shaped by perceptions of friendships, shared ethics, and cultural norms.

This broader, institutional and eco-systemic view of selling highlights the shortcomings of dyadic views with clear distinctions between salespeople and buyers (i.e., salespeople facilitate the delivery of value to buyers). Specifically, it leads to a conceptualization of selling in which selling is commonly performed by a broad range of actors regardless of the term chosen to characterize them (e.g., buyers, users, industry experts, journalists) since all these actors can actively participate in the institutional work processes that shape crossing points. A user, for example, can actively sell a new technology to her management team. Similarly, an industry expert might reject a new solution (i.e., sell the established solution) by pointing to the untested nature of the new solution. In this way, the institutional and eco-systemic view on selling proposed in this chapter can help to reconcile incompatible definitions of selling and salespeople which often rely on whether a good or service is offered in exchange for payment (Hartmann, Wieland, and Vargo 2018, p. 11).

In the same vein, enabled by growing digitization, information can now easily be "liquefied" so that it can be separated and transported independently of people and materials (Normann 2001). This liquefication also helps to overcome dyadic views with clear distinctions between salespeople and buyers. Consider changes in the real estate market. Homeowners and homebuyers have become less dependent on real estate agents, as exemplified by a greater proportion of buyers and owners who are representing themselves, demanding 
agents take a lower fee, or using discount brokers with reduced services. This does not mean that selling in the real estate market has become less important or that the number of crossing points has decreased. Homebuyers and sellers still need to arrive at mutually aligned market values, have trust in relationships and processes, and require guidance with contractual obligations. What has changed is that buyers and sellers now have tools such as Zillow to help them assess inventories and prices, sites to learn about the quality of schools, the safety of neighborhoods, and actors such as Bankrate.com that guide them through financing options.

\section{Research directions}

As we have pointed out above, changes with regard to technologies, industries, societies, etc. will regularly influence which activities selling entails as well as how such activities are performed. Hence, while regular analysis of what activities salespeople perform may be helpful for many pursuits, furthering understanding of what it is that selling fundamentally is may yield rich insights into how salespeople are similar or different and provide answers to many contemporary sales questions. Herein, we have advanced an approach that distinguishes between sales and supporting or administrative activities, accounts for change and continuity, and can be generalized to describe all salesperson (and other actor) positions and roles. We believe this approach raises a number of interesting and timely questions, a subset of which include:

- In what ways, if any, are some sales activities viewed as more important than others by various actors (e.g., managers, customers, analysts)?

- To what extent, if any, are salespersons with a greater proportion of their activities classified as being sales activities (vs. supporting or administrative activities) less likely to find themselves replaced by technologies or processes?

- How, if at all, does technology enable the shift of selling activities to actors who are traditionally not viewed as selling actors?

- Which, if any, components of selling are less/more susceptible to replacement by technology or processes than others?

- How, if any, do sales activities vary across actor categories (e.g., salesperson vs. journalist vs. user)?

- Which, if any, components of selling are more critical to explaining sales generation and maintenance than others?

- How does the proportion of sales activities to total activities performed vary across well-established salesperson roles (e.g., hunters/gatherers)? Are there unexpected differences from expectations and does the institutional systemic view proposed reconcile such differences? 


\section{Conclusion}

In this chapter, building on earlier work from Hartmann, Wieland, and Vargo (2018), we have argued for a broader, institutional, and eco-systemic theoretical foundation for selling. While sales roles, activities, and communication technologies will undoubtedly continue to change, we do not believe that these changes will necessarily alter what selling entails and how actors fundamentally participate in the thinning of crossing points. Specifically, our work identifies that the establishment of mutual definitions of what is being reciprocally exchanged, the establishment of the norms and representations that guide exchange practices, and the establishment of relational norms, such as flexibility, solidarity, mutuality, harmonizing of conflict, and restraint in the use of power, to safeguarding relationships, are foundational to all sales processes. These institutional processes highlight that selling is fundamental to human actors since all human actors participate in service-for-service exchange at thin crossing points. Our framework points to the notion that selling always has been and will continue to be important. Furthermore, our framework conceptualizes broad activities as being sales related since many activities are involved in the alignment of institutional arrangements and optimization of relationships for service-for-service exchange. However, changes in communication technologies (e.g., telephone, social media, video-conference, machine-to-machine), roles, and expectations among other things may shift the sales activities that various actors perform as well as the importance of various tasks. Hence, the importance of what we refer to as the modern salesperson may vary across and within industries, organizations, time periods, etc. We want to encourage sales researchers to adopt an institutional framework going forward since such a framework can, as stated, offer rich insights into the tension between change and continuity in sales activities.

\section{References}

Agnihotri, Raj, Prabakar Kothandaraman, Rajiv Kashyap, and Ramendra Singh. 2012. "Bringing 'Social' Into Sales: The Impact of Salespeople's Social Media Use on Service Behaviors and Value Creation." Journal of Personal Selling \& Sales Management 32 (3): 333-48.

Ahearne, Michael, Ronald Jelinek, and Eli Jones. 2007. "Examining the Effect of Salesperson Service Behavior in a Competitive Context." Journal of the Academy of Marketing Science 35 (4): 603-16.

Alderson, Wroe. 1957. Marketing Behavior and Executive Action: A Functionalist Approach to Marketing Theory. Homewood, IL: Richard D. Irwin. 
Andzulis, James “Mick”, Nikolaos G. Panagopoulos, and Adam Rapp. 2012. "A Review of Social Media and Implications for the Sales Process." Journal of Personal Selling \& Sales Management 32 (3): 305-16.

Baldwin, Carliss Y. 2008. "Where do Transactions Come From? Modularity, Transactions, and the Boundaries of Firms." Industrial and Corporate Change 17 (1): 155-95.

Baldwin, Carliss Y., and Kim B. Clark. 2000. Design Rules: The Power of Modularity. Cambridge, MA: MIT Press.

Bourdieu, Pierre. 1977. Outline of a Theory of Practice. Cambridge: The Press Syndicate of the University of Cambridge.

Chandler, Jennifer D., and Stephen L. Vargo. 2011. "Contextualization and Value-in-Context: How Context Frames Exchange." Marketing Theory 11 (1):35-49.

Chonko, Lawrence B., Eli Jones, James A. Roberts, and Alan J. Dubinsky. 2002. "The Role of Environmental Turbulence, Readiness for Change, and Salesperson Learning in the Success of Sales Force Change." Journal of Personal Selling \& Sales Management 22 (4): 227-46.

Churchill, Gilbert A. Jr., Neil M. Ford, and Orville C. Walker Jr. 1978. "Predicting a Salesperson's Job Effect and Performance: Theoretical, Empirical and Methodological Considerations." Paper presented at the American Marketing Association/Marketing Science Institute Sales Management Workshop.

Cravens, David W., Raymond W. LaForge, Gregory M. Pickett, and Clifford E. Young. 1993. "Incorporating a Quality Improvement Perspective into Measures of Salesperson Performance.” Journal of Personal Selling \& Sales Management 13 (1): $1-14$.

DiMaggio, Paul, and Walter W. Powell. 1983. "The Iron Cage Revisited: Collective Rationality and Institutional Isomorphism in Organizational Fields." American Sociological Review 48 (2): 147-60.

Duddy, Edward A., and David A. Revzan. 1953. Marketing: An Institutional Approach. New York: McGraw-Hill.

Dwyer, Robert F., Paul H. Schurr, and Sejo Oh. 1987. "Developing Buyer-Seller Relationships." Journal of Marketing 51 (2): 11-27.

Evans, Kenneth R., Richard G. McFarland, Bart Dietz, and Fernando Jaramillo. 2012. "Advancing Sales Performance Research: A Focus on Five UnderResearched Topic Areas." Journal of Personal Selling \& Sales Management 32 (1): 89-105.

Giddens, Anthony. 1984. The Constitution of Society: Outline of the Theory of Structuration. Berkeley, CA: University of California Press.

Hartmann, Nathaniel N., Heiko Wieland, and Stephen L. Vargo. 2018. “Converging on a New Theoretical Foundation for Selling." Journal of Marketing 82 (2): 1-18.

Hughes, Douglas E., Joël Le Bon, and A. Rapp. 2013. "Gaining and Leveraging Customer-Based Competitive Intelligence: The Pivotal Role of Social Capital and Salesperson Adaptive Selling Skills." Journal of the Academy of Marketing Science 41 (1): 91-110.

Humphreys, Ashlee. 2010. "Megamarketing: The Creation of Markets as a Social Process." Journal of Marketing 74 (2): 1-19.

Jolson, Marvin A. 1997. "Broadening the Scope of Relationship Selling." Journal of Personal Selling \& Sales Management 17 (4): 75-88.

Kjellberg, Hans and Claes-Fredrik Helgesson. 2006. "Multiple Versions of Markets: Multiplicity and Performativity in Market Practice." Industrial Marketing Management 35 (7): 839-55. 
Lamont, Lawrence M., and William J. Lundstrom. 1974. "Defining Industrial Sales Behavior: A Factor Analytic Study." In Proceedings of the American Marketing Association, edited by R. C. Curham, 493-8. Chicago, IL: PAMA.

Lawrence, Thomas B., and Roy Suddaby. 2006. "Institutions and Institutional Work." In The SAGE Handbook of Organization (2nd edition), edited by Stewart R. Clegg, Cynthia Hardy, Tom Lawrence, and Walter R. Nord, 215-54. Thousand Oaks, CA: SAGE.

Marshall, Greg W., William C. Moncrief, and Felicia G. Lassk. 1999. “The Current State of Sales Force Activities." Industrial Marketing Management 28 (1): 87-98.

Marshall, Greg W., William C. Moncrief, John M. Rudd, and Nick Lee. 2012. "Revolution in Sales: The Impact of Social Media and Related Technology on the Selling Environment." Journal of Personal Selling \& Sales Management 32 (3): 349-63.

Moncrief, William C. 1986. “Ten Key Activities of Industrial Salespeople.” Industrial Marketing Management 15 (4): 309-17.

Moncrief, William C. 2017. "Are Sales as We Know It Dying ... or Merely Transforming?" Journal of Personal Selling \& Sales Management 37 (4): 271-9.

Normann, Richard. 2001. Reframing Business: When the Map Changes the Landscape. Hoboken, NJ: John Wiley \& Sons.

North, Douglass C. 1990. Institutions, Institutional Change, and Economic Performance. Cambridge: Cambridge University Press.

Nunan, Daniel, Olivier Sibai, Bruno Schivinski, and George Christodoulides. 2018. "Reflections on 'Social Media: Influencing Customer Satisfaction in B2B Sales' and a Research Agenda.” Industrial Marketing Management 75 (November): 31-6.

Plouffe, Christopher R., and Donald W. Barclay. 2007. "Salesperson Navigation: The Intraorganizational Dimension of the Sales Role." Industrial Marketing Management 36 (4): 528-39.

Plouffe, Christopher R., Willy Bolander, Joseph A. Cote, and Bryan Hochstein. 2016. "Does the Customer Matter Most? Exploring Strategic Frontline Employees' Influence of Customers, the Internal Business Team, and External Business Partners." Journal of Marketing 80 (1): 106-23.

Plouffe, Christopher R., Srinivas Sridharan, and Donald W. Barclay. 2010. "Exploratory Navigation and Salesperson Performance: Investigating Selected Antecedents and Boundary Conditions in High-Technology and Financial Services Contexts." Industrial Marketing Management 39 (4): 538-50.

Rackham, Neil, and John DeVincentis. 1998. Rethinking the Sales Force: Refining Selling to Create and Capture Customer Value. New York, NY: McGraw-Hill.

Rapp, Adam A., Daniel G. Bachrach, Karen E. Flaherty, Douglas E. Hughes, Arun Sharma, and Clay M. Voorhees. 2017. "The Role of the Sales-Service Interface and Ambidexterity in the Evolving Organization.” Journal of Service Research 20 (1): 59-75.

Revzan, David A. 1968. "The Holistic-Institutional Approach to Marketing." In Perspectives in Marketing Theory, edited by Jerome B. Kernan and Montrose S. Sommers, 97-136. New York: Appleton-Century-Crofts.

Scott, Richard W. 2013. Institutions and Organizations: Ideas, Interests, and Identities (3rd edition). Thousand Oaks, CA: Sage Publications.

Sewell, William H. 1992. "A Theory of Structure: Duality, Agency, and Transformation.” American Journal of Sociology 98 (1): 1-29.

Simon, Herbert A. 1996. The Sciences of the Artificial. Cambridge: MIT Press. 
Singh, Jagdip, Karen Flaherty, Ravipreet S. Sohi, Dawn Deeter-Schmelz, Johannes Habel, Kenneth Le Meunier-FitzHugh, Avinash Malshe, Ryan Mullins, and Vincent Onyemah. 2019. "Sales Profession and Professionals in the Age of Digitization and Artificial Intelligence Technologies: Concepts, Priorities, and Questions." Journal of Personal Selling \& Sales Management 39 (1): 2-22.

Vargo, Stephen L., and Robert F. Lusch. 2004. "Evolving to a New Dominant Logic for Marketing." Journal of Marketing 68 (1): 1-17.

Vargo, Stephen L., and Robert F. Lusch. 2008. "Service-Dominant Logic: Continuing the Evolution.” Journal of the Academy of Marketing Science 36 (1): 1-10.

Vargo, Stephen L., and Robert F. Lusch. 2016. "Institutions and Axioms: An Extension and Update of Service-Dominant Logic." Journal of the Academy of Marketing Science 44 (1): 5-23.

Vargo, Stephen L., and Robert F. Lusch. 2017. "Service-Dominant Logic 2025." International Journal of Research in Marketing 34 (1): 46-67.

Weitz, Barton A., and Kevin D. Bradford. 1999. "Personal Selling and Sales Management: A Relationship Marketing Perspective." Journal of the Academy of Marketing Science 27 (2): 241-54.

Weld, Louis D. H. 1916. The Marketing of Farm Products. New York: Macmillan.

Wieland, Heiko, Nathaniel N. Hartmann, and Stephen L. Vargo. 2017. "Business Models as Service Strategy." Journal of the Academy of Marketing Science 45 (6): 925-43.

Wieland, Heiko, Kaisa Koskela-Huotari, and Stephen L. Vargo. 2016. "Extending Actor Participation in Value Creation: An Institutional View." Journal of Strategic Marketing 24 (3-4): 210-26.

Wilson, David T. 2000. "Deep Relationships: The Case of the Vanishing Salesperson." Journal of Personal Selling \& Sales Management 20 (1): 53-62.

Zeithaml, Valarie A., A. Parsu Parasuraman, and Leonard L. Berry. 1985. "Problems and Strategies in Services Marketing." Journal of Marketing 49 (2): 33-46.

Zietsma, Charlene, and Brent McKnight. 2009. Building the Iron Cage: Institutional Creation Work in the Context of Competing Proto-Institutions. Cambridge, UK: Cambridge University Press.

Zimmermann, Erich W. 1951. World Resources and Industries. New York: Harper and Row. 
Nathaniel N. Hartmann, Heiko Wieland, and Bruno Lussier - 9781788975315 Downloaded from PubFactory at 04/26/2023 10:50:02AM via free access 